\title{
LA CREACIÓN DE RECTORÍAS EN LUGARES DE MORISCOS DE LA DIÓCESIS DE ORIHUELA POR EL OBISPO JOSEP ESTEVE, 1597
}

Juan B. Vilar

\section{PRESENTACIÓN}

En el Archivo Catedral de Orihuela, Arm. IX, leg. XIX, o bien leg. 1.126 (signaturas antiguas), existe un expediente, el 15 -renumerado 21-, con el rótulo Erección de los Curatos [de] los Lugares de Moriscos del Obispado de Orihuela, 21 folios, que tuve la fortuna de hallar en la primavera de 1976, y que me fue de gran utilidad en la redacción de un extenso estudio, Los moriscos de la gobernación y obispado de Orihuela, publicado en la revista Al-Andalus dos años más tarde ${ }^{1}$, y al propio tiempo en la elaboración del capítulo correspondiente de mi libro Orihuela, una ciudad valenciana en la España moderna, obra aparecida por las mismas fechas ${ }^{2}$.

No obstante lo dicho, y a que el estudio publicado en Al-Andalus no dejó de tener un cierto eco en la comunidad científica tanto entonces como después, no faltó quien cuatro años más tarde (1982) presentase como hallazgo propio tal fuente ${ }^{3}$, que dijo haber encontrado ("tuvimos la suerte de encontrar" -!-) cuatro años atrás, precisamente en el verano del 78, meses después de hacerlo público quien suscribe en la entonces revista española arabista de máximo prestigio y difusión. Huelgan comentarios.

* Universidad de Murcia.

1. J.B. VILAR, «Los moriscos de la gobernación y obispado de Orihuela», Al-Andalus, XLIII, fasc. 2, 1978, pp. 323-367.

2. VILAR, Orihuela, una ciudad valenciana en la España moderna, prólogo de Sebastián García Martínez, Murcia, 1981, pp. 125-133 [«Resistencia al proselitismo cristiano. Censo y arreglo parroquial de 1597»], t. IV en VILAR, Historia de la ciudad y obispado de Orihuela, Murcia, 1977-1982, 8 vols.

3. J. MARTíneZ VALS, «Los moriscos de la diócesis de Orihuela a finales del siglo XVI y legislación particular canónica sobre los mismos», Anales de la Universidad de Alicante. Facultad de Derecho, 1, 1982, 243-272. 
En su momento guardé silencio, por cuanto no soy dado a debates estériles que rehúyo por principio, tanto más si ello conlleva un alto riesgo de toparse con la Iglesia (valga la metáfora), y ni siquiera denuncié donde corres pondía "técnicas de investigación" cuando menos de dudosa ética, aunque más extendidas en nuestro gremio de lo que suele aceptarse. Y ello pese a que el investigador de referencia amenazaba con nuevas aportaciones: "Muchas cosas quedan todavía por elaborar y no resistimos la tentación de publicarlas en su día"4. Tanto más por cuanto, a su juicio, "el tema de los moriscos, tan amplio, confuso y casi todavía virgen, lo merece" 5 .

Que sepamos, nuestro flamante y benemérito moriscólogo no ha vuelto sobre el tema. Quién sabe si consciente de que tal temática, amplia en sí, no era tan confusa y virgen como pretendía en su original contribución, por contar ya entonces con una bibliografía casi inabarcable, incluidas contribuciones señeras como las de Longás ${ }^{6}$, Halperin-Donghi ${ }^{7}$, Reglá $^{8}$, Lea $^{9}$, García Cárcel ${ }^{10}$, Benítez ${ }^{11}$, Domínguez Ortiz y Vincent ${ }^{12}$, García Arenal ${ }^{13}$, Epalza ${ }^{14}$ o Cardaillac ${ }^{15}$, por mencionar sólo a algunos de los autores de monografías clásicas especialmente incidentes en la dimensión religiosa de la problemática morisca y en el ámbito valenciano.

Hemos tenido noticia de que la fuente en cuestión va a ser publicada en breve como "descubrimiento" de última hora. Por tanto hemos decidido (es-

4. Ibidem, p. 268.

5. Ibidem.

6. P. LONGÁs, La vida religiosa de los moriscos, Madrid, 1915.

7. T. HALPERIN DONGHI, «Un conflicto nacional: moriscos y cristianos viejos en Valencia», Cuadernos de Historia de España, XXIII-XXIV (1955-1957).

8. J. REGLÁ, Estudios sobre los moriscos, Barcelona, 1974.

9. H. Ch. LEA, The Moriscos of Spain; their Conversion and Expulsion, 2. ed. New York, 1968.

10. R. GARCÍA CÁRCEL, Orígenes de la Inquisición española. El Tribunal de Valencia, 1478-1530, Barcelona, 1976. Del mismo autor: La Inquisición en Valencia, 1530-1609, Barcelona, 1980, y en colaboración con E. CÍSCAR PALLARÉS, Moriscos i agermanats, Valencia, 1974.

11. R. BENÍTEZ SÁNCHEZ-Blanco y E. CísCAR PALlarÉS, «La Iglesia ante la conversión y expulsión de los moriscos», en R. García VillosladA, Historia de la Iglesia en España, t. IV, Madrid, 1979, y E. SALVADOR y R. BENÍTEZ, «Felipe II y los moriscos. El intento decisivo de asimilación, 1559-1608», en Estudios de Historia de Valencia, Valencia, 1978, pp. 183-201.

12. A. Domínguez OrTiZ y B. Vincent, Historia de los moriscos. Vida y tragedia de una minoría, Madrid, 1978 (remite a la nutrida producción de ambos autores sobre el tema).

13. M. GARCÍA-ARENAL, Inquisición y moriscos. Los procesos del Tribunal de Cuenca, Madrid, 1978.

14. M. de Epalza y R. Petit, Recueil d'etudes sur les Moriscos andalous en Tunisie, Madrid, 1973. Referencias a la extensa obra sobre el tema del primero de esos autores pueden verse en su reciente monografía: Los moriscos antes y después de la expulsión, Madrid, 1992.

15. L. CARDAILlaC, Moriscos y cristianos. Un enfrentamiento polémico (1492-1640), prefacio de F. Braudel, Madrid, 1979 (ed. francesa, 1977). 
crito esto en noviembre de 1996) hacer lo mismo por nuestra parte en la que es hoy, sin duda, la revista moriscóloga española mejor hecha y de mayor proyección, y dada la urgencia del caso, prescindiendo del preceptivo estudio de esa documentación, obviable por cuanto ya queda hecho en las dos contribuciones ya mencionadas. Todo ello sin ánimo de polemizar ni de volver sobre una cuestión antigua, y que tenemos olvidada, habida cuenta de que las evidencias y el tiempo sitúan a cada cual donde le corresponde.

En cualquier caso lo cierto es que sigue inédita la fuente de referencia, utilizada por los profesores J.B. Vilar y J. Martínez Valls en sus respectivas contribuciones, ya mencionadas, y en otras varias del primero que vinieron después ${ }^{16}$. Que si bien es éste historiador contemporanista, siendo las minorías religiosas una de sus líneas preferentes de investigación, siempre ha mostrado interés por los moriscos en cuanto tal minoría, en particular los aspectos incidentes sobre la catequética y restantes iniciativas desplegadas en la época con mayor o menor éxito para obtener su asimilación religiosa.

La documentación aquí presentada aporta testimonios bastante amplios y completos sobre la realidad morisca survalenciana de finales del XVI. El expediente fue promovido en 1597 por Josep Esteve (o José Esteban), obispo de Orihuela, muy celoso en el cumplimiento de sus obligaciones pastorales, incluida la atención de los moriscos de su diócesis -2.745 vecinos en 1597, unas 7.570 personas, en su mayoría en lugares de la huerta de Orihuela y villas del

16. J.B. VILAR, «Fortificación y defensa del litoral en el sur valenciano», Cuadernos de la Biblioteca Española de Tetuán, 19-20, 1979, pp. 131-164; VILAR, «Callosa de Segura (Alicante) en la coyuntura de 1579», Revista del Instituto de Estudios Alicantinos, 34, 1980, pp. 164-204; VILAR, «Moriscos granadinos en el sur valenciano», Estudis, 9, 1983, pp. 15-47; VILAR, «Las “ordinaçiones” del obispo Tomás Dassio, un intento de asimilación de los moriscos de la diócesis de Orihuela», en L. CARDAILLAC (coord.), Les Morisques et leur temps, París, 1983, pp. 385-410; VILAR, «Un intento de aculturación de los granadinos internados en Murcia y su reino. Ordenanzas del obispo A. González Gallego e instrucción sinodial cartaginense de 1571», Actes du II Simposium International de la C.I.E.M. sur Rèligion, Identité el Sources documentaries sur les Morisques Andalous, II, Túnez, 1984, pp. 167-187; VILAR, «Rebelión y dispersión de los moriscos: el caso murciano», en J. PÉREZ VILLANUEVA y B. ESCANDELL (dirs.), Historia de la Inquisición en España y América, I, Madrid, 1984, pp. 772-780; VILAR, «L'Inquisition de Murcie», cap. XV en L. CARDAILlaC y B. VInCENT (coords.), Les Morisques et l'Inquisition, París, 1990, pp. 241-257; VILAR, «Hallazgo de una biblioteca morisca en Potries (Gandía) en 1789», Sharq al-Andalus, 5, 1988, pp. 147-152; VILAR, «Murcia en la inmigración morisca en Túnez», cap. VI en VILAR, Mapas, planos y fortificaciones hispánicos de Túnez (s. XVI-XIX) / Cartes, plaus et fortifications hispaniques de la Tunisie (XVI ${ }$.-XIX ${ }^{e}$. s.), prólogo de M. de Epalza, Madrid, 1991; VILAR, Los moriscos del reino de Murcia y obispado de Orihuela, Murcia, 1992; VILAR, «La expulsión de los moriscos del Reino de Murcia: sus efectos demográficos y económicos», en L'Expulsió dels Moriscos. Conseqüències en el món islàmic $i$ en el món cristià (Sant Carles de la Ràpita, 5-9 decembre 1990, Barcelona, 1994, pp. 86-95; VELAR, «Los últimos musulmanes de la ciudad de Villena, a través de tres procesos de la Inquisición de Murcia (1611-1612)», Sharq al-Andalus, 10-11, 1993-94, pp. 720-729 (Homenaje / Homenatge a María Jesús Rubiera Mata); VILAR, «Una biblioteca morisca requisada en 1592 en la villa de Monóvar», Sharq al-Andalus, 13, 1996, pp. 169-181. 
valle del Vinalopó ${ }^{17}$-, hasta el momento bastante descuidados. De otro lado esa documentación no deja de ser un valioso testimonio generado en vísperas de la expulsión. Por ambas consideraciones bien merece sacarla a la luz para conocimiento y utilidad de los, afortunadamente, hoy numerosos investigadores interesados por una temática tan fundamental como apasionante.

\section{ERECCIÓN DE LOS CURATOS [DE] LOS LUGARES DE MORISCOS}

\section{DEL OBISPADO DE ORIHUELA. SU BULLA TRADUCIDA DEL YDIOMA}

\section{LATINO AL CASTELLANO (1) [F. 22R]}

[Acta notarial de la Cancillería Apostólica, 8 diciembre 1675]

In Dei nomine Amen. Sepan todos: Que en el año del Nacimiento de nuestro Señor Jesuchristo [del 1675, día 8 del mes de Diciembre, y el VI del Pontificado de

17. Los datos del censo realizado a iniciativa de Esteve en 1597 son más precisos y fiables que los aportados por P. BORONAT, Los moriscos españoles y su expulsión. Estudio histórico-crítico, Valencia, 1901, pp. 428-442, sobre fecha indefinida, tomado de un censo del XVI realizado también en fecha imprecisa, acaso el publicado por Tomás González.

Censo del obispado de Orihuela, 1597 (en vecinos)

\begin{tabular}{lcccr}
\hline LOCALIDAD & JURISDICCIÓN & $\begin{array}{c}\text { CRISTIANOS } \\
\text { VIEJOS }\end{array}$ & MORISCOS & TOTAL \\
\hline Orihuela (1) & Realengo & 3.000 & 40 & 3.040 \\
Albatera (Orihuela) & Id. & - & 233 & 233 \\
Cox (Id.) & Id. & - & 170 & 170 \\
La Granja (Id.) & Id. & - & 70 & 70 \\
Redován (Id.) & Id. & 32 & 34 & 66 \\
Alicante(2) & Id. & 1.273 & - & 1.273 \\
Elche & Señorío & $?(3)$ & 380 & - \\
Crevillente & Id. & - & 422 & 422 \\
Novelda & Id. & 100 & 400 & 500 \\
Elda & Id. & 70 & 360 & 440 \\
Aspe & Id. & 30 & 386 & 456 \\
Monóvar & Id. & 240 & 250 & 280 \\
Petrel & Id. & 4.825 & - & 240 \\
Total & & 2.745 & 7.570 \\
\hline
\end{tabular}

Fuentes: ACO, IX, XIX; J.B. VILAR, «Los moriscos de la gobernación y obispado de Orihuela», Al Andalus, XLIII, 2, 1978, pp. 323-367.

(1) Incluidas Guardamar y restantes aldeas concejiles, salvo Cox, La Granja y Redován.

(2) Datos de 1602. Vid. P.M. ORTS y Bosch, Alicante. Notas históricas (1373-1800), Valencia, 1971, pp. 35-37.

(3) En 1609, 450 cristianos viejos, según los datos publicados por Tomás GonZÁLEz, Censo de Población..., Madrid, 1829, p. 138. 
$\mathrm{N}[\mathrm{t}] \mathrm{ro}$. S.S. Padre y Señor Clemente, por Divina providencia Papa X de este nombre, Yo el Notario infraescripto, ví, leí y libré copia de cierto breve que original se halla entre los breves secretos de Clemente VIII de feliz memoria, que a estilo de la Curia Romana es como sigue.

[Súplica de Felipe II al papa Clemente VIII para la erección de parroquias en los lugares de moriscos del arzobispado de Valencia y obispados de Tortosa, Segorbe y Orihuela. El pontifice accede]

$\left(1 .^{\circ}\right)$ Clemente VIII. El cumplimiento de nuestra obligación en la dignidad a que sin merecerlo hemos ascendido, indispensablemente pide que, deviendo cuidar de la universal Yglesia, no hagamos otro que pensar en mantener la salud de todas las Almas de los fieles, y en defender y promulgar nuestra Cathólica Religión sin dexar de aprovar todo quanto por los Cathólicos Reyes pudo para estos mismos fines hacerse y ordenarse. Y aunque ya en otros tiempos por el Cathólico Rey de las Españas, Phelipe II, de esclarecida memoria, se nos hizo presente, que para la instrucción de los Moriscos, o de reciente[s] convertidos a la religión Christiana en el Reyno de Valencia, y otras muchas partes, hauía Iglesias Parroquiales, y Vicarías erigidas y dotadas en fuerza de Letras de Gregorio Papa XIII, nuestro predecesor, dadas a los 16 días del mes de Julio de 1576 y 30 de Agosto de 1577, en forma de breve; pero por quanto para la mejor y más [f. $22 \mathrm{v}$ ] acomodada educación e instrucción de estos Moriscos o nuevamente convertidos, y sus descendientes, en la Cathólica feé y Doctrina convenía eregir de nuevo otras Yglesias Parroquiales o Vicarías en los Obispados de Valencia, Tortosa, Segorbe y Orihuela, y augmentar las la eregidas, o menos bien dotadas, añadiéndoles rentas, según y conforme pareciese más combeniente a nuestro ven[erado] Hermano Arzobispo de Vale[encia], [a los] Obispos de Orihuela, Tortosa y Segorbe, o a las personas por estos diputadas para este efecto, deseándolo también dicho Señor Phelipe II, y solicitando se providenciase sobre ello, por tanto Nos, dando gracias a Dios por tan piadoso celo, y queriendo tener aquí por expresas qualesquiera Letras Apostólicas tanto de Gregorio XIII como de qualquier otro concedidas a ese thenor, inclinándonos a las súplicas de dicho Rey Phelipe II, encargamos al Arzobispo de Valencia y Obispos de Tortosa, Segorbe y Orihuela, para que qualquiera de estos en sus respectibas Diócesis, tierras y lugares, en los que habitasen hasta el presente los Moriscos o descendientes de estos, y en donde no se huviessen aún erigido Yglesias Parroquiales o Vicarías, puedan según y más conveniente les pareciere erigir de nuebo Iglesias, dottarlas y dividirlas, $o$ [a] las ya erigidas acrecerle su congrua y dotte, con tal que las erecciones, fundaciones, divisiones, distinciones, aplicaciones, quotas y dotaciones de congruas y dottes ya hechos y aplicados [f. $23 \mathrm{r}$ ] y de rentas y de limosnas pertenecientes a semejantes mejoras, ya sean conforme prescribe Gregorio XIII, n[t]ro. Predecesor, o como mejor pareciere a los Arzobispos y Obispos, o les hiciesen todos juntos y de común acuerdo, o ya cada uno de por sí, se señalen y particularmente se especifiquen, y assí señaladas, y especificadas, y reducidas a pública Escritura, se de noticia de ellas a nos y a esta Santa Sede Apostólica, para que de esta suerte podamos establecer, determinar y ordenar lo que más pueda conducir para mayor gloria de Dios, más acertada institución, y utilidad de los Moriscos o nuevamente convertidos, y para la pureza de las demás Yglesias, dando y concediendo a los dichos Arzobispo y Obispos, y a cada uno de ellos (authoritate n[t]ra. utendo) toda la authoridad llena, libre, absoluta y apostólica que fiase necesaria para todo lo referido, y juntamente todo el poder que más largamente consta, y es dever, en otro breve

$\left(2 .^{\circ}\right)$ Semejante a este expedido en 27 de Febrero de 1597, y seis de nuestro Pontificado. Pero hauiendo (a semejanza de lo expuesto poco ha por el Rey Phelipe 
II, y del Ven[erable] Hermano Joseph Estevan, Obispo de Orihuela), dicho Joseph, Obispo, visitados todos los Lugares de su Obispado de Orihuela que se componen de tales nuevamente convertidos, o sus descendientes, e igualmente haviendo considerado maduramente todas estas cosas, y aquellas que pudiesen conducir para el ma[yo]r cumplimiento de nuestros mandatos y enseñanza de dichos recién convertidos a Nuestra Cathólica y verdadera feé, cumpliendo de esta suerte con la obligación de su oficio Pastoral, y considerando que en dicho su Obispado [f. 23 v] havía onze Lugares de Neófittos (como se verá), que conbenía instruir en la feé Cathólica y sus preceptos, lo mismo que a los demás xristianos, como también que podía hir en aumento dichas Instrucciones. Por tanto, siguiendo la forma del Venerable Arzobispo de Valencia, que en fuerza de un Breve de Gregorio XIII hizo varias erecciones, fundación, divisiones y distribuciones de Iglesias Parroquiales, redujo las erecciones, etc., de los dottes ya hechos y aplicados, y de las rentas y limosnas de las Yglesias Parroquiales y Vicarías en la forma siguiente:

\section{[Súplica a la Santa Sede de Josep Esteve, obispo de Orihuela, para que se erigiesen las nuevas parroquias en su diócesis]}

"A N[t]ro. S.S. Señor Clemene VIII, J[oselph Estevan, Obispo de Orihuela, desea salud y ofrece su obediencia después de besar los Pies de los Apóstoles.

He recibido las Letras de vuestra Beatitud, o su copia, concedida[s] en forma de Breve, a ruego y súplicas de Phelipe II, Rey de las Españas, que a la letra son como se sigue:

En nombre de la S[antí]s[ima] e individua Trinidad, Padre, Hijo y Spíritu Santo amén.

Sepan todos y cada uno de los que vieren y leyeren las presentas Letras, que se ve y lee también en ellas: Que nos Ors. Avelo Santes, Protonitario Apostólico de N[ttro. S[antí]s[mo] Papa, y de su Secretario Gen[era]l Auditor de todas las causas de la Curia Romana, juez ordinario de todas las sentencias y censuras, assí pronunciadas en la Curia Romana como fuera de ella, y universal y mero executor nombrado por el mismo S[antí]s[imo] $\mathrm{S}^{\text {or }}$. Papa para qualesquiera Letras Apostólicas, vimos, leímos y con gran cuidado observamos unas Letras Apostólicas de N. S.S. P[adre] [f. 24 r] en Christo Clemente, por Divina Providencia Papa VIII de este nombre, que se expedieron en forma de Breve según costumbre de la Curia Romana con el Sello del Piscator sobre dottación de las Parroquiales de los Moros, las quales están sanas y perfectas, no viciadas ni canceladas, ni en alguna de sus cláusulas sospechosas, antes bien (como a primer[a] vista aparece) sin vicio alguno ni sospecha, cuyo tenor es como se sigue:

\section{[Breve de Clemente VIII erigiendo las nuevas parroquias]}

(3..$^{\circ}$ A los Ven[erables] Her[manos] en Xristo, Arzobispo de Valencia y Obispos de Tortosa, Segorbe y Orihuela, desea salud y apostólica bendición Clemente Papa VIII. Venerables Hermanos: Poco ha nuestro muy amado hijo en Xristo, Phelipe II, Rey de las Españas, hizo hazernos presente: Que aunque ya de antes havía erigidas en el Reyno de Valencia muchas Yglesias Parroquiales y Vicarías, y dotadas en fuerza de Letras Apostólicas de Gregorio XIII, de feliz memoria, expedidas en 17 de julio de 1577 para la Ynstrucción de los Moriscos, o nuevamente convertidos, a la Religión Cathólica en dicho Reyno. Pero por quanto para la mejor y más acomodada educación de dichos Moriscos o nuevamente convertidos, y sus descendientes, en la Cathólica Religión y doctrina, conviene erigir de nuebo otras Parroquiales Yglesias y Vicarías en dichos Obispados, principalmente en el de 
Segorbe [y] Tortosa y Orihuela, y a las ya erigidas y dottadas incompetentemente aumentar sus dottes y rentas según y como bien visto fuere a vuestras fraternidades o personas ex_[f. $24 \mathrm{v}$ ] peditas por vos [y] a este fin nombradas. Por tanto el mismo Rey cuidó se nos suplicase humildemente para que proveyésemos sobre esto. Y Nos, hallanándonos a las súplicas del referido Phelipe II, y dando gracias a Dios de su santo celo, queremos tener por expresas y presentes qualesquiera Letras Apostólicas de Gregorio, nuestro predecesor, o de qualesquier otro, concedidas a este tenor, concediendo a vuestras fraternidades por el tenor de la presente, y os mandamos en quanto qualesquiera de vosotros en sus respectibe Diócesis, tierras y lugares, en los que habitan hasta el presente los Moriscos, o descendientes de éstos, y en donde no se huviesen aún erigido Yglesias Parroquiales o Vicarías, pueda según y como más conveniente le pareciere erigir de nuebo Yglesias, dotarlas y dividirlas, o las va erigidas acrecentar su congrua y dotte, con tal que las erecciones, fundaciones, divisiones, distinciones, aplicaciones, quotas y dotaciones de congruas y dottes ya hechos y aplicados, y de rentas y limosnas pertenecientes a semejantes mejoras, ya sean hechas conforme prescrive Gregorio XIII, nuestro Predecesor, o según mejor os pareciere a todos juntos, o a cada uno de por sí, se señalen y particularmente se especifiquen, y assí señaladas y especificadas, y reducidas a pública Escritura, se de noticia de ellas a nos, y a esta Santa Sede Apostólica, para que de esta suerte podamos establecer, determinar y ordenar lo más impor [f. 25 r]tante a la mayor gloria de Dios, más acertada Ynstrucción y utilidad de los Moriscos o nuevamente convertidos, y para la pureza de las demás Yglesias, dando y concediento a todos y a qualesquiera de vuestras fraternidades todo el poder lleno, libre y absoluto que fuese necesario para todo lo referido, sin que obsten a esta concesión qualesquier otras Constituciones y órdenes Apostólicas por más contrarias que sean. Dadas en San Pedro de Roma y selladas con el sello del Piscator a los 27 de Febrero de 1597, a 6 de ntro. Pontificado. Lugar + del sello.- M. Vestrio Barbiani.

Cuyo Breve assí expedido a pedimento del M. $\mathrm{H}^{\text {ble }}$. Cavallero $\mathrm{D}^{\mathrm{n}}$. Lauro Dabuil, en la Curia Romana Agente [de] Negocios del Poderoso e Ynvicto Rey de las Españas Phelipe II, mandamos reducir a público Ynstrumento, declarando y requeriendo que a esta copia pública, con los demás originales, se les de tanta feé y crédito como se les diera a los mismos originales si se presentasen, interponiendo en todo y qualesquiera de sus partes ntro. Decreto y auttoridad ordinaria, y mandando librar esta copia en todas y qualesquiera de sus partes, y que se signare por el infraescripto Nottario haziéndole unir el sello de que ussamos en semejantes Breves. Dado en Roma, en la casa de nuestra regular havitación a los dos días del mes de Marzo, año del Nacimiento de N.S. Jesuscristo, 1597, y 6 del Pontificado de N. S.S. P. Clemente VIII, por Divina providencia Sumo Pontífice J. Lapio Luis.- Fran ${ }^{\text {co }}$. Ugolini, Nottario apostólico de la Curia Romana'.

Cuyo Breve encendió [f. 25v] en el pecho de Phelipe II tal cuydado y ardiente celo para que los nuevos Christianos, y descendientes de esos, fuesen ynstruidos en la verdadera feé y religión, que como a heredero y sucesor de tal padre, Phelipe III (no solo en el Reyno sino también en el zelo de desterrar la secta mahometana de sus reynos), luego que tomó las riendas del govierno, no tuvo otra mira, que ver como hacer que todos los obispos de sus Reynos pensasen en lo mismo, instruyendo a dicho, nuevamente convertidos en la verdadera Cathólica religión y feé. Acreditando este mismo zelo el ardor con que V. Beatitud paternalmente cuida de poner presbíteros de experimentada religión y letras en todos los lugares de tales Moriscos que exerzan el cura de almas, y con su exemplo y piedad les traygan y mantengan en nuestra verdadera religión y feé. 


\section{[Diligencias del obispo Esteve para dar cumplimiento al Breve papal]}

$\left(4^{\circ}\right)$ Por tanto, deseando obedecer a los preceptos de vuestra Beatitud, y llenar el gusto de Phelipe II, empesé a encargarme de este negocio, y a pensar enseguida el modo y medio más facil y conveniente para la erección de dichas Yglesias Parroquiales, teniendo para este fin presente que en días pasados el Lic $^{\text {do }}$. Feliziano de Figueroa, decano y canónigo de la Yglesia de Valencia, varón muy habil y experimentado en todo negocio, y de acreditada virtud, costumbres y doctrina, para satisfacer los Reales deseos [f. 26 r] ya premeditó atentamente este negocio, y juntamente con Juan Bautista Torner, canónigo de Orihuela, mi Vicario General, y para este fín mi diputado, examinó atentamente las rentas, emolumentos y frutos que pareciesen necesarios para el Dotte y sustentación de las dichas Parroquiales Yglesias de mi Obispado, como también reduxo a recto orden y arreglo todo aquello que pudiese conducir a este negocio, lo qual haviendo mandado ver y examinar diligentemente, no pude menos de aprobarlo y de remitirlo a $\mathrm{V}$. Beatitud con el respeto devido, y principalmente si se advierte que las erecciones, fundaciones, divisiones, distinciones de dottes la aplicados, y de rentas pertenecientes al aumento de dichas Yglesias Parroquiales están prescriptas y colocadas con tal orden, que ni se pudo hacer ni desear mejor.

Por lo que remito a V. Beatitud todo quanto los dichos Feliziano Figueroa y Juan Bautista Torner, mi Vicario General, huviesen destinado, conferido, escrito y trabajado para este efecto, para que se digne la S[anta] Silla aprovarlo y confirmarlo, y vea V. Beatitud lo que a V. S[antidad] rendido humildemente pido. Y el tenor de lo trabajado es como se sigue:

\section{[Erección de parroquias en los pueblos de moriscos de la diócesis de Orihuela]}

(5. $\left.{ }^{\circ}\right)$ Hechos de la erección, desmembración y de la dottación hasta cien libras de moneda valenciana, que a voluntad, zelo y dirección de Phelipe II, Rey de las Españas, se han regulado en diferentes Yglesias Parroquiales de los Lugares de Moros poco ha convertidos [f. 26 v] en el Obispado de Orihuela a nuestra verdadera religión.

Oriola. En la Ciudad de Orihuela, cabeza del Obispado, y donde ay a más [de] tres Yglesias Parroquiales con tres mil casas, se hallan 40 casas de Moriscos repartidos por toda ella, sin tener estos ninguna Yglesia Parroquial ni propio parrocho que pueda y deva instruirlos en la Doctrina Christiana, ni conocerles e imponerles en la feé Cathólica. Pero por quanto en la Parrochia de $S^{\text {ta }}$. Justa, y cerca de esta, hay una Yglesia u oratorio con la ynvocación de San Pablo Apostol, que no tiene ningún destino, y a ella pueden acudir dichos Moriscos para ohir misa en los días de fiesta y domingos. Por tanto parece que dicha Yglesia de $\mathrm{S}^{\mathrm{n}}$. Pablo se destine, y en efecto quede destinada, para el expresado fin, así como ya se mandó por el Obispo de Orihuela en su visita. Deviendo uno de los tres curas de la Parroquial Yglesia de $\mathrm{S}^{\text {ta }}$. Justa (guardando turno) celebrar misa en dicho Oratorio en los referidos días, y explicar la Doctrina Christiana a los Moriscos, destinándoles a dichos curas por su salario y trabajo en el referido cargo y obligación mientras $q^{\mathrm{e}}$. en ello estuviesen constituidos trescientas libras anuales por cada uno de dichos beneficios, que deberán sacarse de los frutos de primicias y diezmos del diezmo de Orihuela. Nombrando también el Obispo un alguacil (que podrá a su arbitrio remover) para que a dichos nuevamente [f. $27 \mathrm{r}$ ] convertidos haga hir a misa, y ohir la Doctrina Christiana en dicho Oratorio u Yglesia de $\mathrm{S}^{\mathrm{n}}$. Pablo comp[i]liéndoles y multándoles en caso necesario. 
Redován. Consta Redován de treinta y dos casas de xristianos viejos, y de treinta y quatro de nuevamente convertidos, que todos son 66. Hay en este pueblo Yglesia Parroquial bajo la ymbocación de $\mathrm{S}^{\mathrm{n}}$. Miguel Arcángel desde que los Moros de este Reyno se convirtieron a nuestra Santa Lee Cathólica. La cura de almas se cumple regularmente por un sacerdote mercenario, quien por su mantenimiento y salario tiene las primicias de dicho Lugar, que importan veinte libras, y otras cinco libras que el Obispo y Cabildo de Orihuela, y la Universidad de Valencia contribuyen por razón de los derechos de diezmos que de dicho pueblo perciben, y cincuenta sueldos que el dueño temporal de dicho Lugar por costumbre antigua también paga, que todo hace la suma de $27 £$ [ibras] $10 \mathrm{~s}$ [ueldos].

Y por quanto es muy natural que las obejas tengan pastor propio a quien conozcan, e igualmente él a ellas, que no haga como el criado pagado, que al ver venir el lobo huye, antes bien deva dar su vida, y cuenta a ellas, y deviendo ser instruidos dichos Moriscos en la feé Cathólica, por tanto en dicha Parroquial ecclesia de Redován deve constituirse un rector y parrocho propio, quien exerxa el cura de almas, y quien obtenga dicha Rectoría o Parroquial Yglesia por concurso, según el Decreto de la Sag[rada] Cong[regación], al qual se le señale para siempre, y por congrua, las ante dichas [f. $27 \mathrm{v}] 27 \mathrm{~L} .10 \mathrm{~s}$. con más otras 72 L. 10 s., cumplimiento de las 100 L. moneda valenciana, cuya acidición será assí:

Que la Mesa episcopal de Orihuela pague 29 L. 10 s.; a más de la cantidad que antes pagaba por los diezmos que de dicho pueblo percibe, ascendiendo su valor a 91 L. 2 s. 5 [dineros]. La Mesa capitular pague igualmente 15 L. 13 s. 6 [d.] a más de lo que antes pagaba. Y la Universidad de Valencia contribuya también con 2 L. 7 s., 6 por razón de los diezmos que cada uno respective percibe de dicho pueblo de Redobán -sic-, quedando igualmente para siempre aplicadas aquellas 25 L. que los jurados de dicho Lugar voluntariamente se obligan [a] dar para mantenimiento del Rector que se eligiesse, de cuya obligación consta [noticia] más largamente en el proseso, con las quales se completa la suma de dichas 72 L. $10 \mathrm{~s}$. de la nueba addicción.

Cox. El Lugar de Coix se compone de 170 casas de Christianos nuevos. Hay en él Yglesia Parroquial desde q $\mathrm{q}^{\mathrm{e}}$. los Moros del Reyno de Valencia se convirtieron a la Cathólica religión, cuya Yglesia bajo la ymbocación de San Juan Bautista tiene anexo el Lugar llamado la Granja, que se compone de 70 casas. Su cura de almas hasta el día se ha exercido por un sacerdote mercenario puesto por el Ordinario, quien en los domingos y fiestas celebra dos misas, una en Coix y otra [en] la Granja, que por su salario y congrua ha disfrutado siempre las primicias de dichos pueblos, con más tres caízes y medio [f. 28 r] de trigo por assistir a Coix, y cinco y un tercio por el servicio y asistencia a la Granja, que se han tomado de los diezmos de dichos pueblos pertenecientes al Obispo y Cabildo de Orihuela, y a la Universidad de Valencia. Y por quanto es muy conforme a la razón que todas las obejas tengan pastor propio, a quien conozcan, y él a ellas, que no huya como el mercenario al ver venir al lobo, antes bien que de razón y cuenta de ellas, y principalmente en el día, por dever ser instruidos los Moriscos en la religión Cathólica.

Por tanto, conviene que el Lugar de la Granja se desmembre y separe de la Yglesia Parroquial de Coix, erigiéndose en él otra nueva Parroquia en la forma que ya se dirá. Y que en dicha Parroquial Yglesia de Coix se nombre un pastor y párrocho propio, a cuyo cargo esté la cura de almas, deviendo proveherse por concurso dicha Rectoría o Yglesia Parroquial, según decreto de la Santa Congregación. Y a dicho rector se le señala para sus alimentos y congrua suficiente las primicias del referido lugar de Coix, que en el día están reputadas en $50 \mathrm{~L}$. También tres cahíses y medio de trigo, que a común estimación valdrán 21 L., y estas partidas unidas hacen 
la total de $71 \mathrm{~L}$, que para complemento de las $100 \mathrm{~L}$. de moneda de Valencia se deverán añadir y contribuhir con otras 29 L. en esta forma:

La Mensa episcopal de Orihuela pague 17 L. 19 s 7 a más de los tres cahíses de trigo por razón de [f. 28 v] los diezmos de dicho pueblo, siendo el valor de esos el de 189 L. 10 s. 9. La Mesa capitular de Orihuela pague 9 L. 11 s. 5 por la parte de sus diezmos, que ha[s]ciende su valor a 100 L. 17 s. 10, a más de la dicha cantidad de trigo con que contribuye. Y la Universidad de Valencia de 1 L. 9 s. por las razones referidas, con cuyas 100 L. y demás que puede dar de sy el pié de altar, se mantendrá decentemente el rector, quedando para siempre aplicadas a dicha Parroquial Yglesia las tierras que antes posehía la mezquita, siendo de cargo del cura o jurado de dicho pueblo la administración de dichas tierras, y de sus rentas cuydar la fábrica de la referida Yglesia Parroquial y a la havitación del cura que está en ella muy antigua.

La Granja. La Granja es anexo de la Yglesia Parroquial de Coix, y se compone de 70 casas de xristianos nuevamente convertidos. Su cura de almas ha estado a cargo del sacerdote de la Parroquial de Cox, quien muy de mañana venía a decir la otra misa a la Granja en los días de fiestas y domingos, en atención a distar de Cox solamente un cuarto de hora, y ser el camino muy llano. Pero por quanto en tiempo de lluvias se hace muy dificultoso que un mismo sacerdote cumpla con las referidas obligaciones de dos misas, y explicar en ambas partes la Doctrina Christiana a los nuevamente convertidos a ella, y principalmente quando más instan estas obligaciones como en los días de domingo y fiestas, por tanto parece muy del caso desmembrar y separar a dicho Lugar de la [f. 29 r] Granja del de Coix, y una vez desmembrado y separado quede así para siempre, deviendo erigirse su Yglesia en Parroquial. Y una vez erigida, permanezca vajo la ymbocación de $\mathrm{S}^{\mathrm{n}}$. Pedro Apóstol con su capilla, sacristía, campana, fuente de bautismo y demás derechos de Yglesia Parroquial, y perteneciendo por dottación [el] patronato activo de dicha Yglesia a su dueño temporal, queda a elección de éste el nombramiento del referido rector para su Yglesia, como luego se dirá. Señalando para su dotte 100 L. en esta forma: Que las primicias de dicho lugar, que su valor es 14 L. 12 s., y los 5 c[ahíces] 1 /3 que antes dava el sacerdote de Coix por su salario, queden aplicados a dicha Yglesia y su rector, importando los referidos 5 cha[íce]s $1 / 3$ de trigo que se sacan del montón de los diezmos pertenecientes al Obispo y Cavildo de Orihuela, y a los beneficiados de las Yglesias Parrochiales de Santa Justa y San Tiago la cantidad de 26 L. 13 s. 4, que los tres beneficiados de la Yglesia Parroquial de Santa justa de Orihuela, en atención a no estar obligados a su residencia personal, paguen repartidas por iguales partes 5 L. 10 s. 3, por razón de las 300 L. que cada uno de ellos percibe de los frutos de diezmos, que es por cada uno 36 L. 9. Y los dos beneficiados de la Parroquial de San Tiago de Orihuela, que cada uno tiene 200 L. por un beneficio, paguen por iguales partes 2 L. 4 s. 6 por los mismos motibos. Y a más de lo referido, las 51 L. que para complemento [f. $29 \mathrm{v}$ ] de la dottación de dicha Yglesia se obligó a pagar Don Juan de Rocamora, su dueño temporal, todos los años al cura que fuesse de dicha Yglesia de la Granja, haciendo hipoteca de todos sus bienes, y en especial de una almazara de azeyte sita en el mismo Lugar, pero con la condición y reservación del derecho de presentar siempre la referida Rectoría y Parroquial Yglesia, que quiso perteneciese a sí y sus succesores, y no de otra suerte, deviendo de ser de cargo de los vezinos la fábrica de la Ygleisa y la casa del cura, según la forma y capítulos pactados.

Albatera. El Lugar de Albatera tiene 233 casas de Christianos nuevos, y de ancianos viejos, que todos han... (2).

Hay en dicho lugar Yglesia Parroquial bajo la ymbocación de San Jayme, desde que los Moros del Reyno de Valencia se combirtieron a nuestra Cathólica Religión. Su cura de almas se ha regido por un sacerdote mercenario nombrado por 
el Ordinario, a quien por sus alimentos y salario se les dan las primicias de dicho pueblo, y ymportan 77 L. 16 s. 8, con 6 L. más que la Universidad de Valencia dava para que este sacerdote cuydase la educación de los niños. Y por quanto es muy regular que todas las obejas tengan pastor propio a quien conozcan, $\mathrm{y}$ él a ella, que no haga como el mercenario que huye al ver que viene el lobo, antes bien, que esté obligado a dar cuenta y razón de ellas, y principalmente siendo también precisa en el día la instrucción de los Moriscos en la feé Cathólica.

Por tanto combiene que en dicho Lugar de Albatera se nombre un rector [f. 30 r] perpetuo o párroco, a cuyo cargo esté el cuidado de almas, deviendo obtener dicha Rectoría por concurso, según decreto de la Sagrada Congregación. Y señalarse y aplicársele para siempre, a más de las referidas 83 L. 16 s. 8, otras 16 L. 3 s. 4 para cumplimiento de las 100 L. que se sacarán en esta forma: 40 L. 5 s. que pagará la Mensa episcopal de Orihuela por la parte de diezmos $\mathrm{q}^{\mathrm{e}}$. [en] dicho pueblo percibe, ascendiendo el valor de ésta á 387 L. 16 s. 11. La Mensa capitular contribuirá con 5 L. 6 s. 9, y la Universidad de Valencia con 16 s. 2 por los motibos referidos, encargando que la Yglesia, cuyos fundamentos solamente están hechos, quanto antes se prosiga, y concluya su obra, como igualmente la casa havitación del cura, acomodándose a la situación e idea formada, y las rentas y tierras de las antes Mezquitas queden aplicadas a dicha Yglesia y su administración al cura y ecónomo.

Crevillente. El lugar de Crebillente, que pertenece al Marquesado de Elche, se compone de 422 casas de xristianos nuevos.

Hay Yglesia Parroquial desde que los Moros del Reyno de Valencia se convirtieron a nuestra Catholica religión, cuya cura de almas se ha regido hasta el día por un sacerdote mercenario, a quien por su salario y congruos alimentos daba el señor temporal 50 L. por razón de todos los frutos diezmales que de dicho lugar percibía, $q^{\mathrm{e}}$. su valor ascendía a 600 L. anuales, siendo de su cargo el mantener un sacerdote cura de almas.

Y por quanto es muy constante que todas las obejas tengan pastor propio, a quien conozcan, y él a ellas, quien al ver q. viene [f. $30 \mathrm{v}$ ] el lobo no huya, antes [bien] exponga su vida y de razón de ellas, y más en un tiempo en que se hace tan precisa la ynstrucción de los nuevamente convertidos a nuestra feé Catholica. Por tanto es indispensable constituir en la Parroquial de Crevillente un cura propio que obtenga la Rectoría por concurso, según el decreto de la Sagrada Congregación. Y a quien para su dote y alimentos se le señalan las 50 L. referidas, con más para cumplimiento de las 100 L. se le añaden 25 L. que deberá pagar el dueño temporal, por la misma razón y motibo que pagaba antes las 50 L. solamente, y otras 25 que poco ha hizo obligación de pagar al rector, que se nombrare, la Universidad de dicho Lugar, como es de ver por la escritura que de ello otorgó ante el escribano de dicho Lugar. Y con esto quedará bastantemente dottada la referida Rectoría. Pudiendo con las referidas 100 L. y demás emolumentos de pie de altar mantenerse desentemente su párroco y su casa de havitación. Edifíquese o marque la Universidad de dicho Lugar a sus expensas la casa contigua y la edificada junto a la Yglesia.

Elche. La Arraval de Elche está separado de esta Villa [del mismo nombre], y se compone de 380 casas de Christianos nuevos, que están circuidas de murallas, y para entrar a él solamente ay una puerta. Su Yglesia Parroquial bajo la ymbocación de San Juan Bautista es la que antes fue [f. 31 r] mezquita de Moros. Y de licencia del Ordinario celebra un sacerdote mercenario misa todos los días de domingo y fiestas, y administra el sacramento del bautismo. A quién por su salario y alimentos el Duque de Maqueda, su dueño temporal, acostumbraba dar $12 \mathrm{~L}$. 12 s. y la Universidad de dicho Arraval 18 L. 9 s. Aquel por su $3^{\text {a }}$. parte en diezmos que perci- 
bía del dicho Arraval, que en valor ascendía a 1.500 L., y ésta a cuenta de la primicia, que no acostumbraba pagar.

Y por quanto es combeniente que todas las obejas tengan pastor propio y parrocho, que instruya a los nuebamente convertidos, [y] al ver venir al lobo se mantenga firme y expuesto a dar su vida por ellas. Por tanto, se devía nombrar en dicha Parroquial Yglesia por concurso un párrocho y pastor perpetuo, a quien por su dotte y alimentos queden aplicadas para siempre aquellas $31 \mathrm{~L}$. $1 \mathrm{~s}$., debiéndosele añadir otras 69 L. 19 s. para cumplimiento de las referidas 100 L., que se pagarán en la forma siguiente:

La dicha Universidad pague las 17 L. 11 s. que poco hace [se] obligó contribuir cada año al rector que se nombrare por las primicias que no pagan, a las que añadiendo las 18 L. 9 s. que antes pagaban, hazen la suma de $36 \mathrm{~L}$., con las quales de oy en adelante acudirán. Y de las rentas y censos que posehe la Yglesia, se tomarán y aplicarán 10 L. respecto de asender estas a 50 L. La Mensa episcopal de Orihuela pague 14 L: 6 s.. La Mensa capitular 12 L. 14 s. La fábrica de la Yglesia Parroquial de Santa María de Elche 3 L. 13 s. 4. La fábrica de la Parroquial de San Salvador 1 L. 16 s. 8. Los dos benefíciąf. 31 v]dos de Santa María 5 L. 4 s. por iguales partes. Los dos beneficiados de San Salvador 2 L. 12 s. por iguales partes. Y finalmente la Universidad de Valencia 1 L. 2 s. Cuyas cantidades deverá cada uno respectivamente contribuir por la parte de diezmos que en el término de Elche recogen y perciben.

Cuya dotación de 100 L., con los emolumentos de pie de altar, es muy suficiente, perteneciendo la administración de las rentas que antes fueron de [a] mezquita al párrocho y vicario de dicha Yglesia, cuydando de que la Yglesia empesada se remate a expensas de la Universidad, según la forma convenida, y una vez rematada la obra, la que antes era Mezquita, y en donde en el día se dice misa, destrúyase totalmente sin dejar memoria de ella.

Aspe. El lugar de Aspe se compone de 386 casas de Christianos nuebos y 70 de viejos, que todos hacen el número de 456.

Hay Yglesia Parroquial con la ynvocación de Santa María, que es la mesma que antes era Mezquita de Moros. Su cura de almas se ha exercido por dos sacerdotes mercenarios, a quienes por sus alimentos su dueño temporal Duque de Maqueda y Marqués de Elche acostumbró dar 69 L. moneda valenciana por razón de todos los frutos diezmales que, por concesión Apostólica, percibe de dicho pueblo, ascendiendo su valor de $1.400 \mathrm{~L}$. anuales, y también en virtud de cierta concordia celebrada entre el Obispo y Cabildo de Cartagena, de una parte, y de otra Don Juan Ruiz de Corella, dueño de los lugares de Novelda, Aspe, Petrel y Salinas, sobre los diezmos de dichos [f. 32 r] pueblos. Y con escritura ante Matheo Esteve, notario, a los 30 dias del mes de Agosto, año 1494, otorgada en la Villa de Aspe, se obligó su dueño temporal a mantener en él un sacerdote cura de almas, y la Universidad de Aspe a dar 25 L. por razón de las primicias, por quanto no se davan en fruto a los parrochos.

Y respecto que es muy presiso instruir en la feé Catholica a los dichos nuevamente combertidos, y que tengan éstos pastor propio que no tema a nada, antes bien exponga su vida por sus feligreses, conviene que se constituya en dicha Parroquial Yglesia un rector o párrocho perpetuo, que obtenga dicha rectoría por concurso, y a quien en parte de su congrua se le apliquen y queden aplicadas para siempre las dichas 94 L. Y para cumplimiento de las 100 L., y para alimentar un vicario que es necesario, y para administrar los sacramentos a un tan crecido pueblo, se han de añadir otras 56 L., que con las 94 L. de antes, componen las 150 L., que se deverán pagar en esta forma: 
El dueño temporal pagará por el motivo referido 31 L., que con las 69 L. que antes contribuhía, pagará en adelante 100 L., que es el dotte de la Re[c]toría y re[c]tor. Y dicha Universidad pague otras 25 L. más por razón de las primicias, y así pagará las 50 L. por los alimentos del vicario que poco ha se obligó a pagar todos los años al rector que se nombrare, según escritura recibida por el notario de dicha Universidad.

Y por quanto la Yglesia a donde concurre el pueblo, y se celebran los oficios divinos, es la antigua Mezquita (como sus edificios lo demuestran), y ésta por su antigüedad amenaza ruina, en este sitio, y a expensas de la Universdad, según [f. 32 v] la forma establecida edifíquese otra de nuebo, que luego que fuesse concluida, derritiese la vieja Mezquita, sin dexar memoria de ella, y sus rentas y demás bienes $q^{e}$. le pertenecieron antiguamente queden aplicados a la Parroquia nueva, y la administración de ellos a cargo del ecónomo y rector.

Novelda. El lugar de Novelda se compone de 500 casas, las 100 [de] Xristianos viejos, y las 400 de recién convertidos.

Hay en ella Yglesia Parroquial bajo la ymbocación del Nacimiento de la Virgen, que como demuestra el edificio y sus señales, es la antigua Mezquita de los Moros.

Su cura de almas regularmente ha estado a cargo de dos sacerdotes mercenarios, nombrados por el Ordinario, por cuya dotte y alimentos el Marqués de Tierranueva (3), dueño temporal de dicho pueblo, da 100 L. por razón de todos los diezmos que de él percibe, ascendiendo éstos a 990 L. 8 s. También en virtud de cierta concordia sobre los diezmos referidos entre el Obispo y Cabildo de Cartagena de una parte, y de otra Don Pedro Masa de Lisana (4), dueño de Novelda, y el síndico de la Universidad de Monovar, como es de ver por la escritura otorgada por Juan Martínez, notario, a 20 de Julio de 1498, por la que dicho dueño temporal se obligó a mantener un presbítero cura de almas.

Y por quanto es razón que los nuebamente convertidos sean instruidos en la feé Catholica, y tengan un pastor propio a quien conozcan, y se exponga a dar su vida por sus feligreses, por tanto conviene $q^{e}$. en dicha Parroquial de Novelda se nombre por concurso un cura o parrocho perpetuo, a quien se apliquen para siempre [f. 33 r], y queden aplicadas, las referidas 100 L. de moneda de Valencia, teniendo éste la obligación de mantener un vicario para la administración de Sacramentos, en atenzión a lo numeroso de este pueblo, por cuyo salario y alimentos se deverán añadir otras 40 L. en esta forma:

El referido dueño temporal, por las razones dichas, pague $20 \mathrm{~L}$. a más de las 100 que antes pagava, y de las rentas de la antes Mezquita, que ascienden a 60 L., se tomarán otras 20 L. para la ayuda de dicha dotación y constitución de salario para el ecónomo, cuya dotación de 140 L., con lo que puede dar de sí el pie de altar, es bastante congrua.

Y por quanto los vezinos de dicho Lugar de Novelda, hasta aora no han pagado primicia alguna, sin embargo de deverse estos por derecho divino al propio parrocho, por tanto se ha de cuydar, que luego que se nombre el referido rector perpetuo, conforme viene referido, sean presentados dichos vezinos de Novelda a pagar primicias de todo el trigo y azeytte que cogieren, según se acostumbra pagar en el Obispado de Orihuela. A saber: Por 30 barchillas 1 y una vez tan solamente, cuyas primicias assí pagadas (hecha liquidación) importan $250 \mathrm{~L}$. . Y en caso que el dicho rector perciba enteramente las referidas primicias, quede entonces el dueño temporal de Novelda libre del pago de las 120 L., como igualmente las otras 20 L. aplicadas de la Mezquita antigua. 
Y por quanto ya días hace se empesó la Yglesia nueva, y está por concluirse su obra, y poder concurrir a ella sus vezinos para la celebración de los Divinos oficios, por tanto, luego que se colocase en ella el Santísimo Sacramento [f. 33 v], se derribará la antigua Mezquita, de suerte que los nuevamente convertidos no puedan hazer memoria de ella, y se borre totalmente su secta, quedando adjudicadas a la nueva Yglesia las rentas y campos que antes pertenecían a la Mezquita, y bajo la administración de su parrocho y vicario.

Monóvar. El lugar de Monovar se compone de 280 casas, las 250 son de Christianos nuebos, y las 30 de Xristianos viejos.

Hay en él Yglesia Parroquial bajo la ymbocación de San Juan Bautista, desde que los Moros del Reyno de Valencia se convirtieron a nuestra Cathólica Religión.

Su cura de almas se ha regido por un sacerdote mercenario, por el Ordinario nombrado, a quien por su salario y alimentos el dueño temporal de dicho Lugar dava 60 L. por razón de todos los diezmos que de él percibía, ascendiendo su valor a 1.644 L. 1 s. 3. Y también por motivo de cierta concordia entre el Obispo y Cavildo de Cartagena de una parte, y Don Pedro Maza de Lizaña, señor de la Villa de Novelda, y el síndico de la Universidad de la Villa de Monovar de otra, estando pendiente el pleyto sobre dichos diezmos, como consta por la escritura pública autorizada por Juan Martínez, notario, a los 20 días de julio, año 1498, por la qual se obligó a mantener un sacerdote cura de almas.

Y por quanto es muy puesto en razón, que dichos nuebamente convertidos, que han de ser instruidos en la feé Cathólica, tengan un párroco y pastor propio, que ofrezca su vida por sus feligreses, y esté obligado a dar razón de ellos, por tanto con viene que en dicha Parroquial de Monovar se ponga un rector y párroco propio y perpetuo, que obtenga [f. 34 r] dicha Rectoría por concurso, y a quien se le apliquen para siempre dichas 60 L., y a más de éstas, 40 L. a cumplimiento de las 100 L. de la congrua y alimentos suficientes, que deverá pagarse assí:

El dueño temporal por las razones arriva expresadas dará otras 20 L. más, y las otras 20 L. deverán tomarse y aplicarse a dicho rector, de las rentas que fueron antiguamente de la Mezquita, cuyo valor era el de 48 L. 10 s. cada un año. Y respecto que los vezinos de dicho Lugar no han acostumbrado pagar primicias, por más que sean devidas al propio parrocho por derecho divino, al instante que se nombre rector y parrocho para dicha Yglesia Parroquial, deverán sus vezinos acudir con el pago de primicias, según y conforme se pagan en el Obispado de Orihuela. A saber:

30 barchillas de trigo o cevada, 1 barchilla y una vez tan solamente, etc. Y si hecha la liquidación de la primicia de dicho pueblo, ascendiese su valor a 150 L., en este caso y no de otra suerte, quedará libre el referido dueño temporal del pago de dichas 80 L., como también del de las 20 L. que se tomavan de las rentas de la antigua Mezquita. Edificándose casa abbadía para la havitación del cura, que esté junto a la Yglesia, en el modo acordado, y aplicándose a la Yglesia nueva las rentas de la antigua Mezquita, y assí aplicadas, sea de cargo del rector y ecónomo su adininistración.

Elda. El Lugar de Elda se compone de 360 casas de nuevamente convertidos, y 80 casas de Christianos viejos, que todas hazen el número de 440.

Hay en él una antigua Parroquial Yglesia con el titulo de Sta. Ana.

Su cura [f. $34 \mathrm{v}$ ] de almas se ha regido por dos presbíteros mercenarios destinados para este fín por el Ordinario, a quienes el señor temporal, Conde de Elda, da anualmente 100 L., repartidas por iguales partes por razón de todos los frutos dezimales que de dicho lugar percibe, ascendiendo su valor a 107 L., y también por razón de cierta concordia entre el Obispo y Cabildo de Cartagena de una parte, y de 
otra Don Juan Ruiz de Corella, Conde de Consentaina -sic-, y señor de dicho Lugar de Elda, sobre dichos diezmos, según consta por escritura que autorizó Matheo Esteve, notario de Valencia, a los 30 de Agosto de 1494, por la qual se obligó dicho Conde a mantener en Elda un sacerdote cura de almas.

Y por quanto dichos nuevamente convertidos han de ser instruidos en la feé Cathólica, y deven conocer a su propio pastor y párrocho, que exponga su vida por ellos y de razón de sus almas, por tanto conviene que en dicha Parroquial Yglesia de Elda se nombre un rector o párrocho perpetuo que obtenga dicha Rectoría por concurso y coadjutor suyo para la administración de los Sacramentos, en atenzión a ser el pueblo muy crecido, quedándole adjudicados para siempre por su congrua las $100 \mathrm{~L}$. que el referido dueño temporal pagava, por las causas y razones expuestas. Y para la congrua y mantenimiento de dicho vicario ad nutrem amovible [f. $35 \mathrm{r}$ ] quede anexo y aplicado para siempre un simple Beneficio fundado en el altar mayor de dicha Yglesia, bajo la imbocación de Santa Ana, por D ${ }^{\mathrm{n}}$. Juan Coloma, Conde de Elda, que renta anualmente $75 \mathrm{~L}$. pagaderas perpetuamente por sus succesores, a cuya paga será presisado el Conde que por tiempo fuese. Y dicho vicario estará obligado a hacer y cumplir todas las cargas de dicho Beneficio, cuya dottación del rector de dichas 100 L. juntamente con los emolumentos de pie de altar, que importarán unas 80 L., será suficiente congrua para sí, y el vicario o beneficiado, cuydando de que quanto antes se remate la $3^{\mathrm{a}}$ parte de la obra de la Yglesia, que queda [por concluir], y de que la casa habitación del cura se edifique según el sitio y forma convenida, derribando la antigua Mezquita de Moros que en el día está bajo la ymbocación de Santa Cathalina Martir, respe[c]to que en ella aún se advierten algunas reliquias de la maldita secta de Mahoma, y los campos y rentas a ella pertenecientes se aplican a la nueva Yglesia bajo la administración del rector y ecónomo.

Petrel. El Lugar de Petrel se compone de 240 casas de Christianos viejos.

Hay una Yglesia Parroquial muy antigua bajo la ymbocación de San Bartholomé.

Su cura de almas se ha gobernado por un presbítero mercenario puesto por el Ordinario, a quien el dueño temporal Conde de Elda ha dado 35 L. anuales por razón de los frutos que de dicho pueblo percibe, ascendiendo el valor de éstos a 700 L., y también por razón de cierta concordia sobre dichos diezmos entre partes del Obispo y Cabildo [f. 35 v] de Cartagena, y $\mathrm{D}^{\mathrm{n}}$. Juan Ruiz de Corella, Conde de Consentayna -sic-, y dueño temporal entonces de Petrel, según escritura otorgada por Matheo Estebe, nottario de Valencia, a los 30 de agosto de 1494, por la que dicho Conde se obligó a mantener en dicho lugar un sacerdote cura de almas, pagando también sus vezinos $15 \mathrm{~L}$. para complemento de las $50 \mathrm{~L}$. que por razón de las primicias devían pagar y no lo acostumbravan.

Y por quanto es muy regular que los nuevamente convertidos de dicho Lugar sean ynstruidos en la feé Cathólica, y que tengan propio párrocho y pastor, que exponga su vida por sus feligreses, y eleva dar razón de ellos, por tanto conviene que en dicha Parroquial de Petrel se constituya un perpetuo rector o párrocho, en quien se provea la Rectoría por concurso, y a quien se le adjudique por su congrua, y queden adjudicadas para siempre, las referidas $50 \mathrm{~L}$. que el dueño temporal y vezinos del expresado pueblo acostumbravan pagar por las causas y razones expuestas. Y a más de estas 50 , se le adjudicarán otras 50 L. para complemento de las 100 L. de congrua del rector, que las deverán pagar en esta forma:

El dueño temporal dará otras 20 L. más de aquellas 35 L. que por los motivos referidos ya antes pagava. Y la expresada Universidad pague otras 25 L. por razón de dichas primicias, que juntamente con las 15 que antes pagava dará en adelante 40 
L., cuya cantidad se obligó a pagar anualmente dicha Universidad al rector que se nombrase, según escritura authorizada por Gonzalo Ferrandis, nottario de la Villa de [f. 36 r] Elda. Y de las rentas de la antigua Mezquita, que importan 25 L. 7 s. 11, se tomarán 5 L., y se aplicarán al mismo rector. Cuya dottación de 80 L., juntamente con los emolumentos que puede producir el pie de altar, que serán unos 20 p[eso]s, es suficiente congrua. Deviendo edificarse una sacristía y casa abbadía para la Habitación del rector, según la forma acordada, y las rentas y campos de la antigua Mezquita quedardn aplicados a la nueba Yglesia bajo la administración del cura y ecónomo de esta Yglesia.

Yo, el Liz ${ }^{\text {do }}$. Feliziano de Figueroa, deán y canónigo de la Yglesia Metropolitana de Valencia, director nombrado por el religioso zelo del $\mathrm{S}^{\mathrm{r}}$. D ${ }^{\mathrm{n}}$. Phelipe II, Rey de España, juntamente con Juan Bautista Torner, canónigo de Orihuela y vicario general por su $\mathrm{R}^{\mathrm{do}}$. Obispo $\mathrm{D}^{\mathrm{n}}$. Joseph Estevan, diputado y con bastantes poderes encargado de reconocer y averiguar lo más combeniente para la mejor ynstrucción en la feé Catholica a los nuebamente convertidos a ella en los lugares del Obispado de Orihuela, para hacer las erecciones, desmembraciones y dotaciones, y para poner en limpio y reducir a escritura todos los aumentos de dichas dottes, y a hechos, o que convenía hacer en muchas Yglesias Parroquiales, he estado con dicho oficial y vicario general en todos los lugares de Moriscos del expresado Obispado de Orihuela, que son 11 a más de la Ciudad de Orihuela. A saber: Redobán, Coix, La Granja, Albatera, Crevillente, Arraval de Elche, Aspe, Novelda, Monovar, Elda y Petrel.

Y hauiendo indagado ante todo el valor de los frutos, assí de primicias como de diezmos, y hecho averiguación, examen y liquidación de aquellas partes con que cada uno [f. $36 \mathrm{v}$ ] de los que reciben dichos frutos deben contribuhir para las expresadas dotaciones, examinando al mismo tiempo larga y maduramente quanto puede pertenecer a la inmunidad de dichas Parroquiales, y salvación de las almas de los nuevamente convertidos, he hecho las referidas erecciones, dismembraciones, aumentados de congruas, liquidaciones y demás apliaciones, según me ha parecido más conveniente y arreglado a la prorrata de cada uno. Y haviéndolas puesto por escrito, he guardado y seguido el mismo estilo que observé en las dottaciones de semejantes Parroquiales del Reyno de Valencia por encargo del Señor Juan de Rivera, Arzobispo de Valencia, que también aprobó la Santa Sede Apostólica.

Y para que a lo referido se de enteramente feé y crédito, firmo de mi mano, haciendo también poner mi sello. EL LIZ ${ }^{\text {Do }}$. FELIZIANO DE FIGUEROA, Canónigo y Decano.

Yo Jayme Pablo Pallarés, Presbítero Beneficiado de la $\mathrm{S}^{\text {ta }}$. Yglesia de Valencia, y Notario Apostólico, Doy feé: Haver intervino en todo lo referido juntamente con el $\mathrm{L}^{\text {do }}$. $\mathrm{D}^{\mathrm{n}}$. Feliziano de Figueroa, Decano y Canónigo de Valencia, y con Juan Bautista Forner, Off $^{1}$. y Vicario General de Orihuela, haviendo otorgado Escritura pública de todo lo expresado. Y para que en todas partes, assí en juicio como fuera de él, se le dé entera feé y crédito, signé y firmé. = Lugar + del signo.- JAYME PABLO PALLARÉS, el arriva nombrado Presbítero y Notario.- Lugar + del sello.

\section{[Índice de contribuyentes para la erección de parroquias]}

$\left(6^{\circ}\right)$ Yndice de todos [f. $37 \mathrm{r}$ ] los que contribuyen. A saber: la Mesa espiritual, la Mesa capitular, la Universidad de Valencia, los Señores temporales, las Universidades de los Lugares, las fábricas y beneficiados, y las rentas de las antiguas Mezquitas.

El Obispado de Orihuela contribuye a la dotación de las Parroquiales de los lugares en donde poco ha se convirtieron a la feé, tanto por antigua oblighación, como 
por la nueva dotación de 100 L. desde el año 1596, pagando la Mesa episcopal a dichas Parroquias por antigua obligación 16 L. 16 s., y por la nueba dottación 71 L. 15 s. La Mesa capitular de Orihuela por antigua dotación pagava a dichas Parroquiales 8 L. 9 s., y por nueba dottación paga 43 L. 5 s. 8 [dineros].

La Universidad de Valencia paga a las expresadas Parroquias por antigua obligación 1 L. 1 s., y por nueba dottación, 5 L. 14 s. 8 [d.].

Los dueños temporales de dichos lugares pagan a sus Yglesias por obligación antigua 426 L., y por la nueva dottación $167 \mathrm{~L}$.

Las Universidades de los lugares por antigua obligación y costumbre pagan a las mismas Parroquiales, a más de las primicias que en frutos se pagan en algunas partes, 64 L. 9 s., y por la nueba dottación pagan 117 L. $11 \mathrm{~s}$.

Las fábricas y beneficiados pagan 92 L. 7 s. 5. Solamente por la nueba dottación pagan también de las rentas de las antiguas Mezquitas, $55 \mathrm{~L}$.

\section{[Aprobación por el mitrado oriolano de la erección de nuevas rectorías en los lugares de moriscos de su diócesis]}

$\left(7^{\circ}\right)$ Joseph Estevan, por la Gracia de Dios y de la Santa Sede Apostólica, Obispo de Orihuela, etc., Vista esta dotación de las Ygleisas Parroquiales de algunos lugares de nuestro Obispado, comprehensiba de 18 foxas de papel, y hecha para la mejor ynstrucción de aquellos que poco ha se han convertido a otra. Santa feé. Por quanto dicha dotación [f. 37 v] es en evidente utilidad de dichas Parroquias y sus parroquianos, por tanto, y por el thenor de las presentes, ynterponemos nuestra autoridad y Decreto judicial, assí en orden a dicha dotación como en todo lo demás (salvo quedando en todo, y por todo, el beneplácito de N[uestro] S[antísimo] P[adre] y de su Santa Sede Apostólica), en feé de todo lo qual, y en término de todo lo que antecede, mandamos hacer y expedir estas nuestras Letras, firmadas de nuestra mano, selladas con nuestro sello, y por el Ntro. Not[ar]io y Es[criban]o, y de nuestra Curia en devida forma testimoniadas.

Dadas en nuestro Palacio Episcopal de Orihuela a los 14 días del mes de Abril, año del Nacimiento de Ntro. Señor [de] 1597. Siendo presentes por testigos, y para lo referido llamados, Luis Gutiérrez, Presbitero, y Francisco Gisbert, familiares de casa.- JOSEPH, OBISPO DE ORIHUELA. Lugar + del sello.

Yo Juan Bautista Berbegal, Escrivano público por especial comisión del Colegio de Escrivanos, por auttoridad Apostólica Notario del Archivo de la Curia Romana, y en él alistado, y Escrivano de la Curia Eclesiástica de Orihuela, por quan to assistí en todo lo expuesto, juntamente con los referidos testigos, y ví hoi hacerse assí. Por tanto, y obedeciendo el mandatto de mi Señor Obispo, puse mi firma y acostumbrado signo en feé y testimonio de todo lo que antecede.- Lugar + del signo.

Este arreglo, B[eatísi]mo P[adr]e, de adjudicación y señalamiento de congrua, comprehendido en las foxas antecedentes, y dispuesto por el Lcdo. Feliciano de Figureoa y Juan Bautista Torner, mi Vicario general, me ha parecido muy del caso, y digno de la aprovación y confirmación de Vuestra Santidad, conteniendo en sí quanto puede conn[f. 78 r]ducir para el mayor provecho y utilidad de las referidas Yglesias Parroquiales, y salud de las almas, y utilidad de los Christianos nuevamente convertidos.

Dios, sumamente bueno, conserve a V. B. mucho tiempo para mayor autoridad y alabanza de la Cathólica Yglesia. Y para que se de feé $y$ testimonio a todo lo expresado, hizimos librar las presentes, firmadas por nuestra mano, selladas con nuestro sello y autorizadas por el infraescripto secretario. Dadas en la Villa de 
Caudete, de nuestro Obispado, a los 15 dias de Febrero, año 1599. JOSEPH, Obispo de Orihuela. Por mandato de mi señor Obispo, LUIS GUTIERREZ, Secretario. Lugar + del sello.

\section{[Aprobación por Bulla de Clemente VIII de la reforma parroquial realizada en Orihuela y su diócesis]}

$\left(8 .^{\circ}\right)\left(9 .^{\circ}\right)$ Pero nos, atendiendo con gran cuydado a todo aquello que es para mayor aumento de nuestra Cathólica feé y salvación de las almas, y conviniendo en los religiosos deseos de los Reyes Cathólicos y de nuestros Venerables Hermanos los Obispos, a quienes no toca la menor parte de este cuydado, inclinándonos a las súplicas de dichos Phelipe II y Joseph, Obispo de Orihuela, que con tanto zelo nos lo han pedido, por tenor de las presentes aprovamos, para siempre confirmamos, y con la firmeza Apostólica, perpetua e inviolable, corroboramos la preinserta designación, y forma de erecciones, desmembraciones y dotaciones de dichas Yglesias Parroquiales, hechas con authoridad Apostólica por Joseph Obispo, queriendo suplir qualesquiera defectos de derecho y hecho que pudieran hacer cometido en la execución de lo que viene expuesto.

Y según lo bien dispuesto prudentemente, considerando y pensando sobre este parti[f. $78 \mathrm{v}]$ cular por el mismo Joseph, Obispo, determinamos y establecemos para siempre por el presente, y respectivamente erigimos, dividimos, desmembramos y aumentamos, e imponemos a la Mesa episcopal de Orihuela, fábrica [y] Mesa capitular de la misma Yglesia de Orihuela, a las dignidades, canónigos, rectores y beneficiados, y a los demás arriba dichos en la Ciudad y Obispado de Orihuela, todas las cargas y pagas que se deven hacer por los [acuerdos] modernos, y qualesquiera qe. por tiempo existieren en el Obispado, Capítulo y por qualesquiera canónigos, rectores, beneficiados y otros, comprehendidos en dicha tassa o arreglo, imponiéndoles la obligación de satisfacerlas enteramente, y en virtud de las presentes Letras perpetuamente todos los años, y en qualquiera parte o lugar $\mathrm{q}^{\mathrm{e}}$. se encontrasen, declarando $\mathrm{q}^{\mathrm{e}}$. dicha taxación no se pueda anular, invalidar ni reducir a menor suma en tiempo ninguno, aunque sea a instancia de los succesores en el Obispado de Orihuela, dignidades, canonicatos y dichos beneficios por ningún motibo ni causa, por más urgente que sea, applicando y apropiando para siempre dicha tasa o suma de dinero por dotte y congrua de cada Yglesia de la[s] arriva divididas o erigidas, que asciende solamente a la suma de $100 \mathrm{~L}$.

De tal suerte que pueden los rectores de dichas Yglesias Parroquiales (entre quienes se ha de distribuir dicho dinero) elegir, nombrar y constituhir colación, exacción y distribución del expresado dinero o suma, del mismo modo y forma que hasta aora ha sido elegido y nombrado por [f. $39 \mathrm{r}$ ] las Parroquiales antes erigidas, o por el rector de ellas, permitiéndosele a dicho colector o distribuidor exigir dicho dinero, y a las personas en que recayere la provisión de las Parroquiales poco ha divididas y erigidas, o a las que ya de antes estaba provehido les sea lícito, sin ser presiso otro permiso, convertir en sus usos y utilidad los frutos que les perteneciessen en la forma que queda expuesto.

Mandando $\mathrm{q}^{\mathrm{e}}$. si dicho Jospeh, Obispo, y sus succesores en la referida Yglesia de Orihuela, y qualesquiera otros nombrados en dicha tasa o arreglo, y que obtubieren qualesquiera dignidades, prelacías o beneficios comprehendidos en la misma tasa, o sus succesores, se retractasen de hacer la expresada paga, o llegando el tiempo no quiessen contribuir con la parte que les toque, siendo ya de su obligación el satisfacerla, incurra dicho Obispo y sus succesores en la pena de no poder entrar en la Yglesia, y los inferiores en la excomunión. De cuyo entredicho y excomunión no podrán alcanzar relaxación, ni absolución, respectivamente el expresado Joseph, 
Obispo, ni sus succesores, como tampoco los inferiores, a menos $\mathrm{q}^{\mathrm{e}}$. hayan satisfecho la parte de dicha tasa que a cada uno toque, o sobre ella se huviesse concordado amigablemene entre el mismo Obispo, succesores e inferiores, y el colector y distribuidor, exceptuándose solamente el caso de hallarse alguno de ellos en el articulo de la muerte.

Pero si permaneciesen por espacio de seis meses, que se devan contar desde el día [en] que venció el plazo de dicha paga en el referido entredicho, y con [f. 39 v] el corazón endurecido estubieren bien hallados (que Dios no quiera) con la expresada sentencia, desde entonces se empezarán a contar otros seis meses, al cabo de los quales si aun permanecen obstinados, el Obispo quede suspenso de la governación y administración de la Yglesia de Orihuela, y los demás queden instantáneamente privados para siempre de dichas dignidades, prelacías y beneficios inferiores.

Determinando también que estas presentes Letras en ningún tiempo puedan ser argüidas de obrepticias o subrepticias, ni de ningún otro defecto ni intención nuestra, impugnarlas ni anularlas, ni estar comprehendidas bajo las rebocaciones, suspensiones y limitaciones de iguales o contrarias concesiones, antes bien sin embargo de estas, quedan en su eficacia y vigor, y quantas veces sucedan tales cosas, tantas declaramos ser tituhidas -sic- respuestas, y enteramente reintegradas, que deben tener su pleno y entero cumplimiento, assí en los rectores de las mismas Yglesias Parroquiales poco ha erigidas por las presentes Letras, como en los de las ya de antemano creadas.

Por lo que si por alguno se intentase obrar contra lo aquí expuesto, ya sea con ciencia o sin ella, deve conocerse de este delito, y declararse por nulo, e i[n]scrito por los jueces comisarios y ohidores de las causas del Palacio Apostólico, y también por los Cardenales del S[anto] R[omano] C[onclave], quitándoles la facultad de juzgarlo e interpretarlo de otra suerte.

Y por tanto encargamos y mandamos por la presente a los Venerables Hermanos Arzobispo de Valencia y Obispo [f. 40 r.] de Theruel, y a mi muy amado hijo el Ohidor González en todas las causas de la Curia y Cámara Apostólica, para que siempre que todos o qualesquiera de ellos fuessen requeridos por parte de los colectores y dichos distribuidores, que en tiempo fuesen, o por los rectores de las expresadas Yglesias nuevamente convertidas, hagan observar a todos las presentes Letras, y qualesquiera cossas en ellas contenidas, y a ellos pertenecientes, sin permitir que nadie les moleste, a todos ni ninguno de ellos por ningún modo, y también que se les pague real y efectivamente, y según la imposición y tasa hecha, y en las presentes Letras contenidas, y según su thesón, aquella suma de dinero contenida en la tasa, y que real y efectivamente se ha de convertir en los expresados ussos.

Y sin embargo, en quanto constare por el Obispo y qualesquiera otros posehedores de beneficios inferiores, y sus succesores, que alguno incurrió en la referida sentencia de entredicho o suspensión, en tanto cuyden que quando hay más concurso en la Iglesia en los domingos y fiestas para celebrar los oficios Divinos, den notticia al público de tal entredicho y suspenso, y de los demás inferiores excomulgados, para que conociendo la noticia, todos les eviten como a tales, hasta que se satisfaga enteramente al dicho colector, distributor y rectores referidos las expresadas sumas, y el assí suspendido, entredicho y excomulgado haya podido merecer el beneficio de la absolución de tales penas.

Cesando por sentencia censuras [f. $40 \mathrm{v}]$ y penas eclesiásticas. $\mathrm{Y}$ por todos los demás remedios que fueren convenientes a todos los contraventores, $\mathrm{y}$ que no quieren obedecer lo referido, sin embarazar dichas penas ninguna interposición de apelación, y también para que declare el incurso en dichas penas, censuras y setencias, 
valiéndose para ello de los prosesos que fuere preciso ordenar, ynvocando y valiéndose en caso necesario de la justicia secular contra los assí rebeldes y reincidentes, no siendo de consideración alguna sobre este particular diversas reglas de nuestra Apostólica Cancelaria de no expedir concesión de pensión anual sobre beneficio alguno sin consentimiento de aquel que deue pagarlas por razón de dicho beneficio. Ni tampoco el de no quittar el derecho adquirido, ni el de el Conc[ilio] Lateranen[se] nuevamente celebrado, que prohibe dicha pensión sobre rentas de qualesquiera Mesas episcopales e Yglesias metropolitanas, como no sea por cesión u otra causa justa, ni el de Bonifacio VIII, de feliz memoria, ni el del Concilio General, ni siendo de valor alguno contra lo dicho otras Apostólicas Constituciones, y decretos de dicha Yglesia de Orihuela, aunque sean firmes por juramento, confirmación Apostólica o por qualquier otro título, confirmando e innovando quantos Estatutos, costumbres, indultos, privilegios o Letras Apostólicas concedidas bajo qualesquiera forma, tenor, cláusulas y decretos en general o en especial a la misma Yglesia, y a su Capítulo, y a las personas que en él tu [f. 41 r]viessen dignidades, personadas, administraciones, o qualesquiera oficios o beneficios.

A todas las quales por esta vez declaramos nulas, y derogamos especialmente con todo lo demás, que pueda ser contrario a esta nuestra presente Bulla, dexándolas en lo demás en su fuerza y valor. Y de la misma suerte que si de todas ellas se hubiesse hecho expresa mención, assí las tenemos aquí por expresas y presentes. Por si acaso el Obispo de Orihuela, o sus succesores, tuviessen Privilegio de la Silla Apostólica para no poder ser entredichos, suspendidos ni excomulgados sino por Letras Apostólicas, que hagan plena y expresa mención, y de palabra por palabra, de qualquier yndulto a ellos concedidos.

Queremos también que a qualquier copia de este escrito, aunque sea ympresa, se le dé entera feé y crédito, assí en juicio como fuera del, con tal que vaya legalizada por algún nottario público, o sellada con el sello de alguna persona constituida en dignidad eclesiástica, y la misma que se le diera al original si se presentase en juicio. Como también que si mis Amados Hijos Deán y Cabildo de la Yglesia de Orihuela, y demás que puedan tener interés en la dottación y erección de dichas Yglesias Parroquiales, dentro de los primeros seis meses que se contarán desde el día de la notificación de las presentes Letras que se va a hazer a dicho Cabildo, se encontrasen perjudicados en alguna cosa por motibo de lo expuesto, puedan hazer su recurso al Venerable Hermano Arzobispo de Valencia, quien conociendo sumariamente de sus exempciones, y enterado enteramente tanto de la quan[f. $41 \mathrm{v}]$ tidad de la tasa, como del modo y tiempo a pagarla, y de los términos en que deven empesar dichas pagas, atendiendo solamente a la verdad, declare lo que le pareciere justo, assí como por la presente le concedemos autoridad Apostólica para dicho fin, sin dar lugar a apelaciones.

Dado en Roma, en San Pedro, sellado con el Sello del Piscator a 20 de Mayo de 1602 y 11 de nuestro Pontificado. J. G. LLUSIO.- Lugar + del sello.

\section{[Diligencias notariales]}

Es copia original de los Breves secretos de Clemente VIII, de feliz memoria, y concuerda con el[los] fielmente. De cuya copia, haviéndola visto, lehído y observado, hizo el presente instrumento, a quien -sic- se le debe dar entera feé y crédito, como si presentase el original. Fecho en Roma dichos día, mes y año, siendo presentes por testigos los señores Juan jacinto Heures y Francisco Valentín, rogados y llamados para el expresado fín- P[orque] assí como en el presente, teniendo antecedentemente 16 cartas o foxas, se presentó a la Santa Sede. 
Dichas Letras Apostólicas concuerdan con su original. JAYME DE PACTIS, Oficial Diputado.CARD. RIZ.- Lugar + del sello.- Lugar + del signo.- Assí es.- INOCENCIO DE LAURENTIS, Notario, Diputado de la Canchillería -sic-Apostólica.

\section{[Índice del documento presentado]}

Abstracto -sic- de esta Bulla y explicación de los números de su margen.

El Num ${ }^{\circ} .1^{\circ}$ refiere la súplica del $\mathrm{S}^{\mathrm{r}}$. Phelipe II al Papa Clemente VIII, y concesión de éste al Arzobispo de Valencia y Obispos de Tortosa, Segorve y Orihuela, para que puedan en los Lugares de Moriscos de sus respectibos Obispados, erigir, desmembrar y dottar [f. 42 r] las Yglesias Parroquiales, con tal de que lo que obrasen sobre este particular, lo avisen y den notticia a la Curia Romana, cuya concesión en forma de Breve se lee al Num 3.

Núm ${ }^{\circ}$. $2^{\circ}$. Supónese hecha la misma súpplica por el Señor Joseph Estevan, Obispo de Orihuela, y a su continuación explica dicho Obispo los motivos para pretender lo mismo que el Señor Patriarcha y Arzobispo de Valencia.

Núm ${ }^{\circ} .3^{\circ}$. El Breve y concesión insinuado[s] [en] $\mathrm{Num}^{\circ} 1$.

Núm ${ }^{\circ}$. $4^{\circ}$. Diligencias de Joseph Estevan, Obispo de Orihuela, para el mejor acierto en la dirección de las nuevas erecciones, y aumentos de congruas, de las expresadas Parroquias de Moriscos, y [mención de] los encargados para este efecto.

Núm ${ }^{\circ} 5^{\circ}$. Copia de lo trabaxado y dispuesto por los encargados de hacer el abstracto y arreglo de rentas para el aumento de dichas congruas y Parroquias de los onze Pueblos de Moriscos. Y al margen avisa lo que se hizo en cada uno.

Núms. $6^{\circ}$ y $7^{\circ}$. Aprovación del Obispo de Orihuela de lo trabaxado y dispuesto por dichos encargados, con el Indice del núm. $6^{\circ}$, de todos los que contribuyeron y contribuyen con sus rentas para dicho aumento de Parroquias y sus congruas.

Núm ${ }^{\circ} .8^{\circ}$. Aprovación Pontificia de lo mismo.

Núm ${ }^{\circ} .9^{\circ}$. El Decreto de erección, desmembración, etc. de las expresadas Parroquiales, según hauía suplicado el Obispo de Orihuela, con otras declaraciones a su continuación”.

\section{Notas}

(1) ACO, leg. 1.126: Erección de los Curatos [de] los Lugares de Moriscos del Obispado de Orihuela. Su Bulla traducida del Ydioma Latino al Castellano, 21 fs. [sig. ant.].

(2) En blanco en el original.

(3) Marqués de Terranova.

(4) Don Pedro Maza de Lizana.

\section{RESUMEN}

Presentación y publicación de la Erección de los Curatos de los Lugares de Moriscos, Diócesis de Orihuela, dispuesta en 1597 por el obispo Josep Esteve, según la copia manuscrita conservada en el Archivo Diocesano d Orihuela. Fuente imprescindible para conocer la situación morisca en ese obispado en 
vísperas de la expulsión, así como el esfuerzo catequizados realizado para la captación religiosa de esa minoría.

Palabras clave: moriscos, conversión, Diócesis de Orihuela, Josep Steve, siglo XVI.

\section{ABSTRACT}

Presentation and Publication of the Settlement of Parishes in the Moorish Areas, Diocese of Orihuela, in 1597 by the bishop Josep Esteve, according to a manuscript copy kept in the Diocesan Archives in Orihuela. A source that is essential to know both the Moorish situation in that bishopric before the expulsion and the catechizing effort made to attract members of that minority.

Key words: Morisco people, conversión, Diocese of Orihuela, Josep Steve, c. XVIth. 